\title{
A model of glacial tectonics, applied to the ice- pushed ridges in the Central Netherlands
}

\author{
DICK F. M. VAN DER WATEREN
}

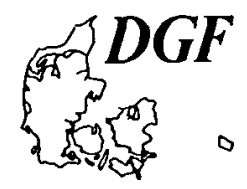

Wateren, D. F. M. van der: A model of glacial tectonics, applied to the ice-pushed ridges in the Central Netherlands. Bull. geol. Soc. Denmark, vol. 34, pp. 55-74, Copenhagen, May, 30th, 1985. https://doi.org/10.37570/bgsd-1985-34-06

During a detailed structural geological and geomorphological survey of ice-pushed ridges around the Gelderse Vallei (centre of the Netherlands) several questions arose about the origin of these landforms.

The Gelderse Vallei is a Saalian glacial basin filled with younger sediments, $40 \mathrm{~km}$ long and up to 20 $\mathrm{km}$ wide, running NNW-SSE. Thrust sheets which build up the ice-pushed ridges on either side of the valley were transported away from the centre of the basin. They are up to $25 \mathrm{~m}$ thick and are pushed to a level about $100 \mathrm{~m}$ above the décollement. The thrust sheets, mainly consisting of coarse sand layers, moved as rigid masses, while only the finegrained basal layers deformed by heterogeneous simple shear.

Pore water pressure plays an important role by greatly reducing the sliding friction in the décollement layer. Once a glacial thrust sheet is formed, the weight of the upward moving frontal part (the toe) offers a resistance to movement, which can not be overcome by the basal shear stress of the glacier alone. Basal shear stresses in most glaciers are in the order of $0.1 \mathrm{MPa}(1 \mathrm{bar})$ and appear to be incapable of lifting a toe of the size found in most ice-pushed ridges in the Netherlands.

The article presents a model of a system ice lobe - substratum, which is to a large degree controlled by gravitational forces.

The dilemma may be solved by the concept of the gradient stress field under the marginal area of an ice lobe. This concept was first formulated by Rotnicki (1976). Because ice thickness decreases towards the margin, the substratum is subjected to a decreasing load in the same direction. If the increments of stress difference under a slab of ice in the marginal zone are summed, a gradient stress is arrived at which is di-rected towards the ice edge.

An estimate of the forces involved in the static equilibrium around the glacier margin indicates that the contribution by the gradient stress field is sufficient to move the toe.

In the model proposed in the article, the energy to move and imbicate glacial thrust sheets around the margins of an ice lobe, is supplied by the continuous flow of ice into the ice lobe. The dimensions of icepushed ridges are thus to a high degree functions of the thickness of the ice lobe or icecap. The Gelderse Vallei ice lobe will have been at least $250 \mathrm{~m}$ thick to be able to form the ridges.

The basal shear stress contributes less to the tectonic transport, the larger the thrust sheets and the higher the ice-pushed ridges.

Dick F. M. van der Wateren, Laboratory of Physical Geography and Soil Science, University of Amsterdam, Dapperstraat 115, NL-1093 BS Amsterdam, The Netherlands. January 25th, 1984.

\section{Introduction}

The present article is the result of several questions which arose during geological and geomorphological fieldwork in ice-pushed ridges around the Gelderse Vallei in the centre of the Netherlands (van der Wateren 1981a, 1981b). The article does not aim at providing the definitive answers to these questions, but in part 3 a dynamic model is proposed as an effort to explain the phenomena related to glacial tectonics.

\section{Ice-pushed ridges}

In the Netherlands and in the better part of the Northern European Plain the deformations caused by the Scandinavian icecaps find their expression in the landscapes as elongate hills. These hills, ranging from less than $10 \mathrm{~m}$ to more than $100 \mathrm{~m}$ in height, are called "Stauchrücken", "Stauchendmoränen" and "Stauchmoränen" in German and "push-moraines" and "ice-pushed ridges" in English. In the Netherlands the use of the term "stuwwallen" is advocated, which is similar to "ice-pushed ridges" and "Stauchrücken". Thus, it is possible to distinguish between landforms largely built up of glacial material (terminal moraines s.s., push-moraines etc.) and landforms consisting of preglacial material and glacio-fluvial sediments, more or less as a whole transported by glacier ice (ide-pushed ridges, Stauchrücken). 
An ice-pushed ridge can be defined as an elongate ridge, or series of parallel elongate ridges, consisting of material mainly of non-glacial origin, which has been transported and deformed by ice action. Cleraly, this is a working definition, as there are several transitional landforms which are hard to fit into it (see: Moran 1971). The internal structure of ice-pushed ridges can be nicely compared with the structures known from foreland thrust belts, like the Jura Mountains, the Canadian Rocky Mountains or the westernmost part of the Appalachian Mountains (Hobbs et al. 1976). Dominant structures in most ice-pushed ridges are imbricated thrust sheets and, less so, parallel inclined and recumbent folds. Depending on the age of the landforms, these structures may express themselves morphologically as a series of parallel depressions and ridges, superposed upon the larger landforms (Gripp 1929, Kälin 1971). With the older ice-pushed ridges, e.g. those in the Netherlands, which all date from the Saalian, the micro-morphology is an expression of the lithology rather than the internal structure (de Jong 1952, 1962, Maarleveld \& de Lange 1977).

The area from which glacial thrust sheets have been removed, is now a depression: a glacial basin (or "tongue basin"; Jelgersma \& Breeuwer 1975a) often filled with younger sediments. In drill cores they are often recognized as fensters (Christiansen \& Whitaker 1976, Jelgersma \& Breeuwer 1975a).

In the Netherlands the ice-pushed ridges form part of several lines of landforms (of which some are buried), usually interpreted as recession lines, i.e. lines corresponding to relatively stationary phases in the general retreat of the Saalian ice-sheet (Maarleveld 1981, see also Boulton 1979). Other authors (among others: Moran et al. 1980) consider the ridges a result of glacier advance.

In the centre of the Netherlands three stages or recession lines are distinguished (Maarleveld 1953, 1981): lines a, b, c. In the Northern Netherland two more lines are distinguished (ter Wee 1962).

The area under consideration, the Gelderse Vallei, is referred to figure 1.

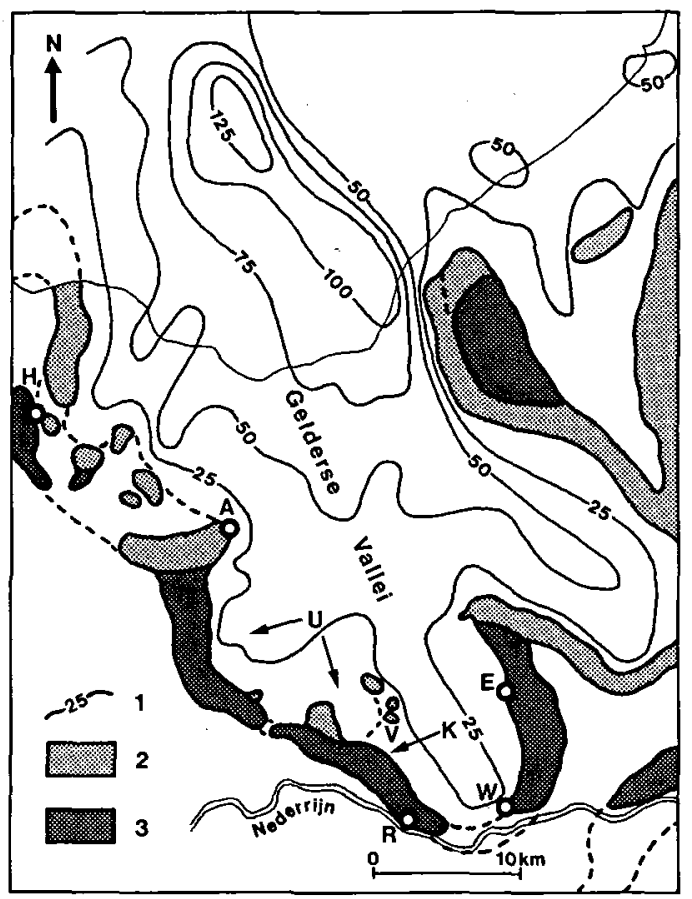

Fig. 1. The Gelderse Vallei glacial basin. After: Maarleveld (1981) and Jelgersma \& Breeuwer (1975).

Legend: 1 - depth below NAP (Dutch Datum Level) of the base of the glacial basin, 2 - ice-pushed ridge line a, 3 - icepushed ridge line $\mathrm{b}, \mathrm{H}$ - Hilversum, $\mathrm{A}$ - Amersfoort, $\mathrm{U}$ Utrecht Ridge (Utrechtse Heuvelrug), V - Veenendaal, K Kwintelooijen sandpit, R - Rhenen, W - Wageningen, E Ede.

Permafrost and glacial thrusting

There is little doubt that permafrost really existed at the time the Pleistocene ice-sheets reached western Europe. Controversies exist, however, as to the nature and extent of the permafrost. In the north of the Netherlands ice wedges and kryoturbation are reported from sand layers immediately below Saalian tills and above interstadial deposits (Zagwijn 1973). Such evidence is at present lacking in the centre of the Netherlands.

Evidence of the thickness of the permafrost and the active layer immediately prior to the arrival of the icesheets is hard to obtain. Most of the estimates stated in the literature are arrived at indirectly. For example, one way of reasoning is that the lower boundary of a glacial thrust sheet coincides with the lower boundary of the permafrost (Richter et al. 1950). Figures thus ob- 
tained have little value for the present discussion.

Another confusing circumstance, at least in the Netherlands, is the almost complete lack of periglacial phenomena in layers which are thrust by ice. Most ice wedge casts postdate the deformation and are found either in glacio-fluvial material overlying Saalian thrust sheets, or can be ascribed to Weichselian permafrost. The extreme rarity of ice wedge casts in glacial thrust sheets may even cause one to suspect that permafrost was absent in the sediment subject to glacial deformation.

Several factors influence the thickness and distribution of permafrost. There is reason to believe that the Saalian ice sheets reached their maximum extension some time after the climate had reached its minimum. This implies that there was sufficient time for permafrost in the foreland to develop.

On the other hand, the possibility of a relatively oceanic climate in western Europe must be considered. If indeed oceanic circumstances prevailed during the Saalian climate minimum in the Netherlands, permafrost would have been thin and discontinuous.

Several facts disagree with a strong oceanic influence. During the colder parts of the Saalian the coast lines in the North Sea area retreated hundreds of kilometres to the west, due to the lowering of the sea level. There is evidence of eolian activity immediately prior to the arrival of the Saalian icecap, which is found in layers under the Saalian till and above Holsteinian interglacial sediments. These layers have much in common with the Weichselian Older Coversands (Maarleveld 1981, pers. comm.). Finally, peat layers from the Bantega Interstadial immediately before the arrival of the Saalian icecap show pollen spectra dominated by Pinus (Maarleveld 1981, pers. comm.).

However, it can be doubted that permafrost in western Europe was ever as thick as it is in Siberia. Permafrost thicknesses of many hundreds of metres seem to be the result of the cumulative effect of several glacials, due to the extreme continentality of the Siberian climate. Nearer to the Atlantic coasts permafrost could completely disappear during interglacial (and maybe also during some interstadial) times.

It is then safe to conclude that before the arrival of the Saalian icecap a continuous perma- frost existed throughout western Europe. Permafrost may have been absent only near rivers and deep lakes.

The next question concerns the effect of a permafrost on glacial tectonics. It is wise, at this stage, to define the concept of permafrost more precisely. The term is often used rather vaguely, to the effect that permafrost is identified with a soil bound by ice. Permafrost in a stricter sense is a ground, which is subjected to temperatures below the freezing point for longer than a year. The concept applies to hard rock as well as to unconsolidated sediments. The latter may contain varying amounts of water and are then more or less bound by ice, or completely cohesionless. To avoid vagueness it seems better to refer to the ice content and ice-bound condition of the sediments in question. In coarse sediments "dry permafrost" is often observed, with at most thin ice coatings around the grains. If the soil temperature is sufficiently low, clay layers in the same soil are found frozen.

Many authors (e.g. Berthelsen 1979, Kupsch 1962. Richter et al. 1951, Schindler et al. 1978) consider permafrost, or rather, an ice-bound substratum a prerequisite for glacial thrusting.

In the models of glacitectonic deformation by Banham (1975) and in the model of glacier-bed landforms by Moran et al. (1980) glacial thrusting is restricted to an outer, frozen bed zone of the icecap. These models imply that thrust sheets were cemented by integrainal ice.

Other authors assume that "permanent ground ice can aid the development of ice-thrust features, but may not be a necessary condition" (Mackay \& Mathews 1964). In his excellent review of glacitectonic structures and related landforms, Viete (1960) leaves the question of a frozen condition of glacially disturbed layers open (Viete 1960: 113).

Laboratory experiments strongly suggest that for example faults can be generated in loose, dry sand as well as in more cohesive materials (Horsfield 1977, Mandl et al. 1977). The fault blocks move as rigid bodies without detectable internal deformation. The main difference between icecemented and dry soil material is in the stress and energy conditions during faulting.

There is some reason to believe that glacial thrusting of the Dutch ice-pushed ridges took place in material that was not cemented by ice. 
Thrust sheets probably moved from river valleys, where the presence of flowing water and lakes could prevent permafrost to develop.

It may be concluded that ice-bound conditions are not a prerequisite for glacial thrusting and the present article starts from this assumption.

Ice movement and glacial thrusting

Most publications dealing with glacial tectonics, in one way or another implicitly correlate the orientation of glacitectonic structures with the flow direction of the glacier that induced them. The general idea is that deformation of the foreland is caused by forces generated by the ice movement. The present article queries this presupposition and aims at offering an alternative.

Although several models that were proposed give very good explanations for the shearing off of glacial thrust sheets; either by the pore-water pressure mechanism (among others: Banham 1975, Moran et al. 1980) or "large scale block inclusion" (Moran 1971), they do not explain how the foreland relief is actually formed by the glacier.

One important question to be answered is whether ice flow can indeed provide sufficient energy to move a thrust sheet up to (at least) the position it is found to occupy now.

A related question concerns the ice flow in the lobate margins common to many of the great Pleistocene icecaps (e.g. Moran et al. 1980: fig. 5, Boulton \& Jones 1979, Richter et al. 1950). If ice flow is indeed able to supply sufficient energy, can it still do so where glacial basins are surrounded on three sides by ice-pushed ridges? (See fig. 1).

As these questions arose during the field work in the Gelderse Vallei, this area will be taken as an example, but they apply as well to other glacially-thrust terrains.

\section{Glacial tectonics near Rhenen}

The field work conducted during 1978, 1979 and 1980 around the Gelderse Vallei glacial basin consisted of a geomorphological and a detailed structural geological survey. The latter was carried out in several sand pits, of which the Kwintelooijen sand pit in the Utrecht ridge, near Rhe- nen, was the most important (van der Wateren 1981a, 1981b).

\section{Landforms}

The present-day Gelderse Vallei is a low-lying area, about $40 \mathrm{~km}$ long and $20 \mathrm{~km}$ wide, gradually becoming narrower towards the south. The present valley bottom lies between $0 \mathrm{~m}$ and $10 \mathrm{~m}$ above m.s.l., has little relief and is bordered by hills on the eastern and western side. The long axis of the valley runs NNW-SSE.

The glacial basin, which occupies the larger part of the valley, reaches to more than $100 \mathrm{~m}$ below m.s.l. in the northern half, rising to less than $25 \mathrm{~m}$ below m.s.l. in the southern half of the valley (fig. 1). The basin is filled with Saalian till and meltwater deposits, Eemian marine sediments, Weichselian coversands and Holocene fluviatile deposits (Jelgersma \& Breeuwer 1975a).

On the western side of the Gelderse Vallei lies the Utrechtse Heuvelrug (Utrecht Ridge), an icepushed ridge, on average $2500 \mathrm{~m}$ wide, with plateau-like top levels between 45 and $60 \mathrm{~m}$ above m.s.l. (highest top: $70 \mathrm{~m}$ ). The ridge is remarkable asymmetric: the proximal side is steepest $\left(5^{\circ}-15^{\circ}\right)$, whereas the distal side (covered with glacio-fluvial outwash) has slighter slopes $\left(2^{\circ}-5^{\circ}\right)$. This asymmetrical profile seems to agree with the morphology of younger ice-pushed ridges.

On the eastern side of the Gelderse Vallei lies the Ede-Wageningen ice-pushed ridge, which is somewhat lower than the western ridge: plateaulike top levels between 30 and $45 \mathrm{~m}$ above m.s.l., and more than twice as wide as the Utrecht ridge. Slopes on the Ede-Wageningen ridge rarely exceed $5^{\circ}$ and, finally, the ridge does not show the pronounced asymmetry characterizing the western ridge. Both ridges are intersected by many dry valleys, some of which, notably at levels of 7 , 28 and $38 \mathrm{~m}$ above m.s.l., may be ascribed to the action of glacial meltwater (van der Wateren 1981a).

There has been much speculation about the conspicious plateau-like top levels that characterize many ice-pushed ridges in the Netherlands. Some authors see them as the result of erosion by ice moving on top of the ridges: the hypothesis of "glaciplanation" (Visscher 1972).

Another possible explanation is by meltwater erosion (ten Cate \& Maarleveld 1977). Van der 
Wateren (1981a) questions the first possibility as there is no structural evidence and the mechanical explanation is dubious. Moreover, many plateaus show no trace of till.

The second alternative can be doubted in those cases where northern erratics are not found in the field (as on the Utrecht Ridge). On the other hand, it must be borne in mind that glacio-fluvial material in the centre of the Netherlands is extremely poor in Scandinavian components.

An alternative explanation is found in the levelling of the micro-relief on top of the ridges by mass wasting, particularly solifluction under periglacial circumstances (van der Wateren 1981a). Kälin (1971) demonstrated in the Canadian Arctic that very soon after an ice-pushed ridge ceases to be actively formed, depressions, running along the length of the ridge become filled with debris. Mass wasting obscures the micro-relief, thus allowing an easy distinction between active and inactive ridges.

The Saalian ice-pushed ridges in the Netherlands have been exposed several times to periglacial circumstances (during the Late Saalian and the Weichselian). The present landforms then, are to a large extent the result of denudation and erosion.

\section{Kinematic reconstruction of the Utrecht Ridge}

For details about the lithostratigraphy of the thrust sheets exposed at the Kwintelooijen sand pit is referred to Ruegg (1981) and Zandstra (1981). Van der Wateren (1981b) gives a detailed account of the structures found at the same locality. The structural relations and the events causing them, are summarized here.

In broad outline the Utrecht Ridge is built up of a series of imbricately and horizontally stacked thrust sheets, striking approximately parallel to the long axis of the ridge. Thickness varies between a few metres and about $25 \mathrm{~m}$. They consist of Lower and Middle Pleistocene, mainly fluvial sediments. As a rule the lowermost 0.5 to $3.5 \mathrm{~m}$ of a thrust sheet are composed of clay, silt and fine sand beds. The bulk consists of coarse sands and gravels. In the most complete thrust sheets ( $Z$ and B, see fig. 2) the uppermost lithostratigraphic units 9 and 10 are of different lithological nature. The better part of the coarse units is

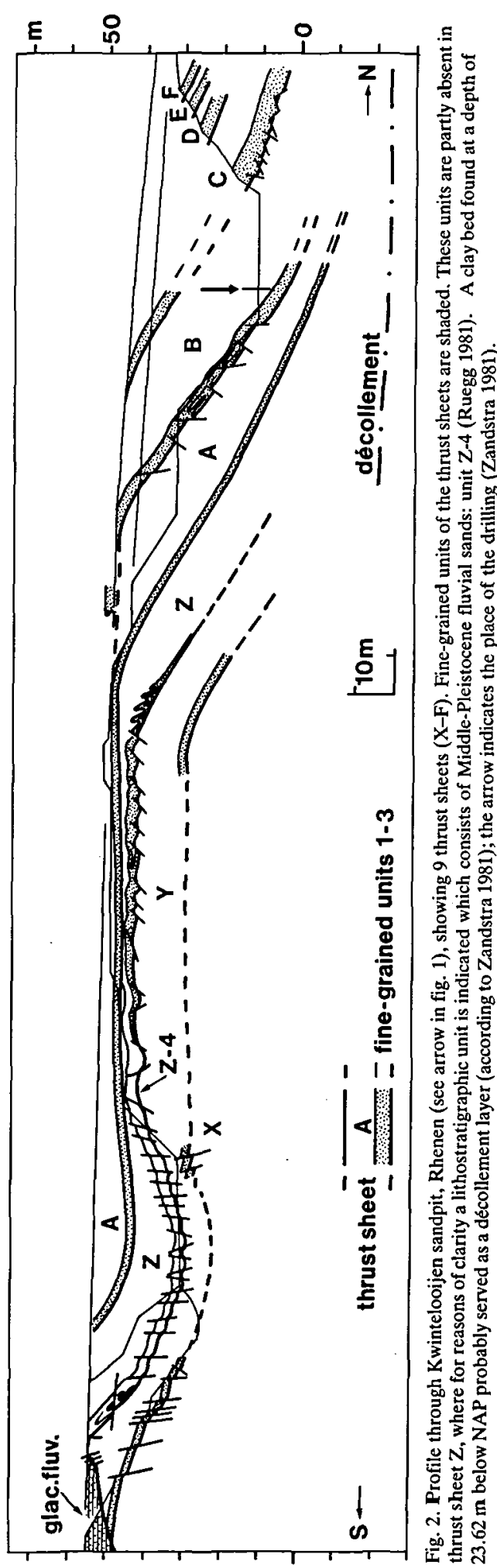


interpreted as part of the sedimentary sequence of a meandering river flowing roughly to the NW. Sedimentary structures in unit 9 suggest an origin as gravity flow deposits. The uppermost unit 10 shows properties characteristic of glacio-fluvial outwash deposits, with flow directions to the SSW (Ruegg 1981). Scandinavian components in units 9 and 10 are scarce, but according to Zandstra (1981) there is enough evidence to assign these units to the Drente Formation (by definition: deposits directly related to the icecap covering the Netherlands during the Saalian Ice Age; Doppert et al. 1975).

A $400 \mathrm{~m}$ long $\mathrm{N}-\mathrm{S}$ profile (fig. 2) shows eight thrust sheets: $\mathrm{X}, \mathrm{Y}, \mathrm{Z}, \mathrm{A}$ to $\mathrm{F}$. In the northern part of the sand pit the thrust sheets are imbricately stacked. Thrust sheets in the central and southern part form a gentle anticline and syncline, with an amplitude of $15 \mathrm{~m}$ and a wavelength of about $400 \mathrm{~m}$. (Note: the present profile is an improved version of the original profile in van der Wateren 1981b.)

A drilling by the Geological Survey of the Netherlands (Zandstra 1981) revealed that, at Kwintelooijen, glacial thrusting occurred at $24 \mathrm{~m}$ below m.s.l. Below this level stratigraphic duplication due to glacial thrusting seems to be absent.

Thrust sheets $\mathrm{Y}, \mathrm{Z}$ and $\mathrm{A}$ are overthrust over a distance of 300 to $400 \mathrm{~m}$. At the crest of the anticline all but unit 4 of thrust sheet $\mathrm{Z}$ are missing, obliquely overthrust by thrust sheet $A$. Coarse units of thrust sheet $Z$ were probably removed by meltwater erosion prior to overthrusting by $A$. In the syncline thrust sheet $Z$ consists of units $Z-4$ to $Z-10$, resting on unit $Y-8$ (thrust sheet $Y$ ). The fine-grained bottom units $Z-1$ to $Z-3$ were left behind while thrust sheet $Z$ climbed the ramp formed by thrust sheets $Y$ and $X$ (see fig. 2).

From the structural relations the movement of the thrust sheets may be reconstructed:

1. During the Lower and Middle Pleistocene terrestrial (mainly fluvial) sediments were deposited in the area of the present day Gelderse Vallei. It is tempting to follow the interpretation by Ruegg (1981) and Zandstra (1981) of the lithostratigraphic units 9 and 10 . These are then regarded as deposits of material eroded from thrust sheets rising in front of the approaching Saalian icecap.

2. An ice lobe invaded the area. From the sub- stratum blocks of fluvial sand and gravel were sheared off, which were $25 \mathrm{~m}$ thick, up to $350 \mathrm{~m}$ long and at least as wide. Moving away from the center of the valley they were forced to climb upthrust planes dipping $30^{\circ}$ to $40^{\circ}$ towards the ice lobe. While the first thrust sheet moved onto the foreland the next one started to move in front of the first, creating a kind of telescoping motion of thrust sheets one over another and over the substratum. Folding of several thrust sheets occurred while they together climbed the next ramp.

The vast majority of meso- and microstructures related to the overthrusting are found in the basal layers. Obviously the coarse sands and gravels moved as rigid blocks, whereas the strain was almost entirely taken up in the fine-grained basal layers. Everywhere the overthrust zone is characterized by a fabric of numerous small isoclinal folds and closely spaced slip planes making small angles with the boundaries of the overthrust zone. Movement occured by flow folding and slip along discrete planes.

3. As soon as the thrust sheets rose above the surface normal faulting set in as a reaction to the changing stress conditions. The direction of the largest principal stress changed from a more or less horizontal to a vertical position, as the thrust sheets came to rest and were only subjected to the force of gravity. A large number of normal faults could be interpreted thus. The resultant lowering of the primary relief is estimated to be at least $20 \mathrm{~m}$. Other normal faults were probably formed earlier as a result of the adjustment of the thrust sheets to local foreland topography. Van der Molen (pers. comm.) suggested a connection with the "escape" of younger thrust sheets from underneath older ones. Indeed, a few normal faults were observed which did not cut the overthrust plane at the bottom of the thrust sheet.

4. Parts of the thrust sheets were removed by meltwater erosion and depressions on top of the ridge were filled with the debris.

5. While telescoping the thrust sheets the ice lobe gradually moved onto the proximal slope of the Utrecht Ridge. Older structures were refolded and horizontal thrust planes and recumbent folds were formed, indicating subglacial deformation.

6. Meltwater formed a system of drainage channels, subsequently filled with glacio-fluvial sands and gravels. These sediments are undis- 
turbed, implying that the tectonic movement had come to rest.

7. Further modification of the relief was mainly by denudation, starting immediately as the thrust sheets were formed. Most of the material was transported away under periglacial circumstances during the Late Saalian and the Weichselian. Hard evidence of the amount of surface lowering is difficult to obtain, but it seems unlikely that more than the thickness of one thrust sheet had been removed. This can be concluded from the many Scandinavian erratics found on top of the thrust sheets outcropping in the proximal slope. This sets the maximum amount of surface lowering to approximately $15 \mathrm{~m}$ : the missing part of thrust sheet $A$ (see fig. 2).

Consequences for a dynamic model of glacial thrusting

In order to explain the formation of ice-pushed ridges a dynamic model must satisfy the following conditions:

1. Thrust sheet movement occurs by simple shear in the basal clay and loam layers. Movement along incompetent beds seems to be the rule in glacial tectonics (see also: Kupsch 1962, Richter et al. 1950, Viete 1960), as well as in "hard rock" nappe tectonics (Hsü 1969, Laubscher 1973). This excludes a mechanism proposed by Schindler et al. (1978) of movement by creep in a layer of ground ice.

2. There is no evidence of an ice-bound condition of the thrust sheets during tectonic transport. Nor is there, for that part, evidence of the opposite. The present model must equally apply to frozen (i.e. ice-bound) as to unfrozen thrust sheets.

Note: many arguments for or against "cold" glacial tectonics in the literature, are based on the appearance of the structures. It must be stressed here that from the structural geometry alone no conclusions can be drawn as to whether the material was frozen during deformation. Such a conclusion requires exact knowledge of the prevailing stress field and strain rate when the structures were formed and also of the mechanical properties of the material. In most cases these parameters remain a wild guess.

3. The décollement in the southern half of the Gelderse Vallei was approximately $25 \mathrm{~m}$ below
m.s.I., as can be deduced from the contour lines of the glacial basin (see fig. 1) and from drilling 39E/185 (see fig. 2). The present top level of the Utrecht Ridge near Kwintelooijen is between 60 and $70 \mathrm{~m}$ above $\mathrm{m} . \mathrm{s} .1$. The numerous normal faults cutting the thrust sheets indicate that the ridge was at least $20 \mathrm{~m}$ higher at the time of formation. Erosion and denudation may have removed an additional $20 \mathrm{~m}$. To remain on the safe side, it is assumed that initially, the ridge rose $\mathbf{1 0 0}$ $\mathrm{m}$ above the décollement.

4. Finally, also the geometry of the Gelderse Vallei as a whole must be taken into account. The ice-lobe which once occupied the valley and which formed the ridges surrounding the valley, was twice as long as wide. From the field evidence at Kwintelooijen and other sand pits and from the strike and dip measurements by Maarleveld (1953) can be concluded that, as a rule, thrust sheets in the Gelderse Vallei dip in a direction almost perpendicular to the long axis of the glacial basin. This implies that a dynamic model of the Gelderse Vallei ice lobe must allow for lateral as well as frontal upthrust and overthrusting.

\section{The mechanics of glacial thrusting}

\section{Basal shear stress}

An icecap on a relatively flat surface seems to have only one means to deform the substratum, i.e. by transmitting horizontal shear stresses. It has been argued that the Pleistocene icecaps, invading lower latitudes, were sometimes forced to move up-slope (Banham 1975). It is conceivable then that the effect of the horizontal normal stress (longitudinal deviatoric stress) becomes more prominent compared to the shear stress acting parallel to the glacier bed (see also: Paterson 1981: 98-101). According to Banham's "valleyside deformation" model the substratum deforms when an ice lobe invades the valley of a river flowing towards the icecap. Banham's "scarp face deformation" model corresponds to the situation of an icecap meeting an escarpment (Banham 1975).

Nevertheless, it may seriously be doubted that the effect of an opposite slope could have been ever so great. Although as yet there are very few 
data about river gradients in the Early and Middle Pleistocene in the Netherlands, these were less than $1^{\circ}$. In fact, gradients may have been even less: between 0.8 and $1.6 \mathrm{~m} . \mathrm{km}^{-1}$, as estimated from E-W profiles through the Netherlands (Jelgersma \& Breeuwer 1975b).

On the other hand, as the sea level at that time was much lower than at present, some steepening of river gradients must be taken into account (Maarleveld 1981, pers. comm.). Still, the effect must not be overrated.

At the moment we are more interested in how a glacier initiates thrust sheet movement even if there is almost no relief when compared with glacier thickness.

As a consequence of the ice flow a glacier applies shear stresses to the substratum. Values for these basal shear stresses cited most frequently in the literature, are in the order of $0.1 \mathrm{MPa}$ (1 bar) (Hobbs 1974). For all practical purposes this may be regarded as the yield stress of glacier ice (Paterson 1981: 86). Yet there are indications that higher basal shear stresses do occur. Measurements in ice tunnels of the shear stresses around rock drumlins give values up to $1 \mathrm{MPa}$ (Boulton 1981, pers. comm.). These high values appear to be local and are related to high strain rates around bedrock hummocks. As these anomal shear stresses occur very locally they seem to be of little consequence for the deformations on the scale considered here.

For the present purpose it seems safe to start from a basal shear stress of $0.1 \mathrm{MPa}$ with a maximum of $0.2 \mathrm{MPa}$.

\section{Shearing resistance of subglacial sediments}

The basal layers of most of the thrust sheets at Kwintelooijen and elsewhere consist of cohesive materials: clay, loam and loamy fine sand. Then the shearing resistance in the décollement layer does not only depend on intergranular friction, but rather on the ductile properties of the material. Exact data are not available, but it can be assumed that deformation in the décollement and upthrust zone is some sort of non-linear viscoplastic flow. Shearing resistance is then approximated by the yield stress of the sediment which can be experimentally determined. However, in the following a simple Coulomb model is prefer- red for a first approximation of the shearing resistance.

In the upthrust zone, the base of the thrust sheet's toe (see fig. 4), different lithologies prevail. As the thrust plane bends upward it cuts through coarse sands making up the bulk of the thrust sheet. In these materials the Coulomb law gives a reasonable approximation of the shearing resistance at the outset of fault formation.

Hubbert \& Rubey (1959) applying the effective stress principle (Terzaghi 1936) to overthrusting, showed that the pressure of porewater in rocks drastically reduces their shearing resistance. According to the Coulomb principle shear failure in a rock takes place when the shear stress across a potential fault plane equals the shearing resistance of the material:

$\tau=\mathrm{c}+\mu \sigma$

in which $\tau$ and $\sigma$ respectively are the shear stress and the normal stress accross the fault plane. $\mathrm{c}$ is a constant: the cohesion of the material and $\mu$ is the coefficient of internal friction $(\mu=\tan \varphi, \varphi$ being often referred to as the angle of internal
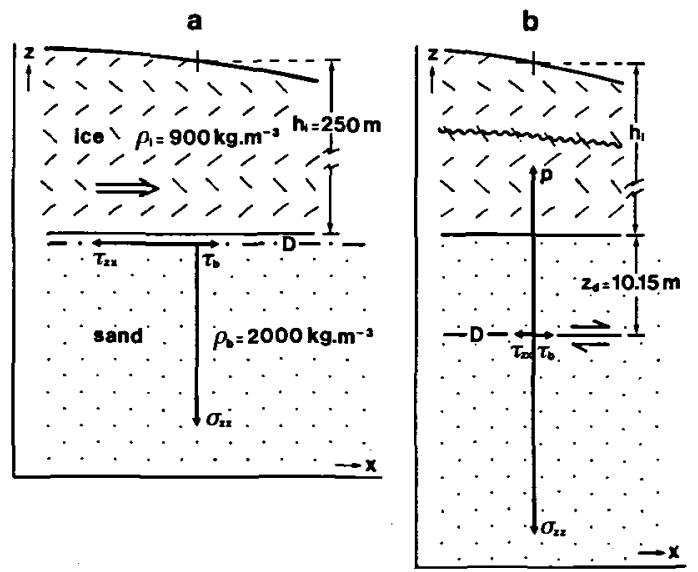

Fig. 3a. Normal stress, $\sigma$ and shear stress, $\tau$ across a plane $D$, in layers of fluvial sand immediately underneath a glacier. Porewater pressure $p=0$ in the sands. Ice thickness $h_{i}=250 \mathrm{~m}$. The shearing resistance $\tau_{z x}$ far exceeds the basal shear stress $\tau_{b}$ transmitted by the glacier.

Fig. 3b. Normal and shear stresses underneath a glacier. Meltwater percolates through the sandy subsoil. A pressure head is maintained $200 \mathrm{~m}$ above the glacier sole: along plane $\mathrm{D}$ at a depth $z_{d}=10.15 \mathrm{~m}, \mathrm{p}=0.86 \sigma_{z}$. Décollement may take place along plane $D$, as $\tau_{2 x}$ now equals $\tau_{b}$. 


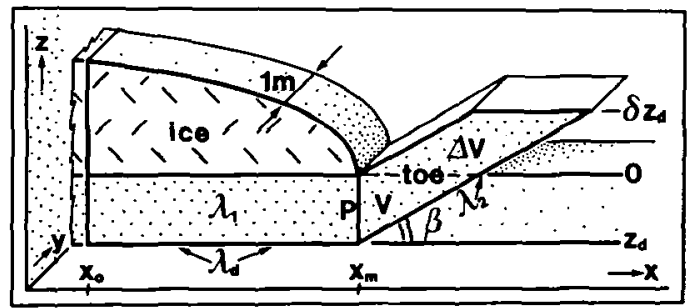

Fig. 4. Coordinate system of ice slab, thrust sheet and toe. The system's y-dimension is $1 \mathrm{~m}$.

$z_{d}$ : depth of décollement layer. $\delta z_{d}$ : height of the toe above the glacier sole, expressed as a fraction of $z_{d} \cdot x_{m}$ : width of the margin zone of the glacier. $\beta$ : dip of the ramp over which the toe slides. $V+\Delta V$ : volume of the toe. P: boundary plane between the subglacial part of the thrust sheet and the toe. $\lambda_{1}$ : quotient of the pore water pressure $p$ and the vertical normal stress $\sigma_{z z}$ in the bulk of the thrust sheet. $\lambda_{d}$ : quotient of $p$ and $\sigma_{z z}$ in the décollement layer at depth $z_{d} \cdot \lambda_{2}$ : quotient of $p$ and normal stress across the basal shear plane of the toe (ramp).

friction). Both $\mathrm{c}$ and $\mu$ are measurable material properties.

Terzaghi (1936) took the effect of pore water pressure into account and stated that:

$\tau=c+\mu(\sigma-p)$

where $p$ equals the pore water pressure. It will be clear that a high pore water pressure will reduce friction, which is why the term $(\sigma-p)$ is often called the "effective normal stress", $\sigma$ '. Many experiments confirmed the validity of Terzaghi's principle.

For the following discussion $\sigma^{\prime}$ is conveniently written as : $\sigma^{\prime}=(1-\lambda) \sigma$, the parameter $\lambda$ being defined by: $\mathrm{p}=\lambda \sigma . \lambda$ is a fraction between 0 and 1. (2) now changes to:

$\tau=\mathrm{c}+(1-\lambda) \mu \sigma$

The following example illustrates the effect of pore water pressure on glacial overthrusting (fig. $3 \mathrm{a}$ and $3 \mathrm{~b}$ ). A body of ice, $250 \mathrm{~m}$ thick, density $\mathbf{g}_{i}$ $=900 \mathrm{~kg} \cdot \mathrm{m}^{-3}$ ) overlies fluvial sands, coefficient of internal friction $\mu=0.58\left(\varphi=30^{\circ}\right)$. The sand has no cohesion: $\mathrm{c}=0$. The water-saturated bulk density of the sediment $\varrho_{b}=2000 \mathrm{~kg} \cdot \mathrm{m}^{-3}$. The gravitational acceleration $\mathrm{g}=9.81 \mathrm{~m} . \mathrm{s}^{-2}$. The normal stress on a horizontal plane $\mathrm{D}$ immediately under the ice equals the ice load.:

$\sigma_{z z}=\varrho_{i} g h_{i} \cong 900 \times 9.81 \times 250 \cong 2.21 \mathrm{MPa}$.
The shearing resistance along $D$ equals the normal stress times the friction coefficient:

$\tau_{z \mathrm{x}}=\mu \sigma_{z z}=1.280 \mathrm{MPa}$.

(Note: suffixes of stress tensor components according to Jaeger \& Cook 1979 and Means 1976). Because the shearing resistance is more than $\mathbf{1 0}$ times the basal shear stress transmitted by the glacier the sands will not fail.

Suppose that, by means of meltwater percolating through the ice, a pressure head is maintained $200 \mathrm{~m}$ above the glacier sole. The water penetrating the sediments sufficiently reduces the shearing resistance for the sediments to fail under a basal shear stress of $0.1 \mathrm{MPa}$. As in reality sediments are anisotropic media, natural faults tend to develop along discontinuities, e.g. bedding planes. If these occur within a depth of about 10 $\mathrm{m}$ failure is expected to take place along one of these planes.

\section{Equilibrium of forces}

In the last section we saw that the pore water pressure plays an essential part in overthrust movement. Yet, the explanation only holds if the moving thrust sheet meets no other resistance than the intergranular friction and cohesion in the décollement zone. Fig. 4 learns that where a thrust plane eventually bends upward, also the weight of the frontal part of the thrust sheet must be considered ("toe effect", Raleigh \& Griggs 1963). The horizontal force driving a thrust sheet, must not only be able to overcome the shearing resistance of the décollement zone, but must in addition be able to support the weight of the upward moving prism: the toe. It is the toe which actually forms the ice-pushed ridge.

Fig. 4 is a diagram of a thrust sheet moving from under the marginal zone of an icecap. An orthogonal set of coordinate axes $x, y, z$ is drawn. $P$ is the imaginary boundary plane between the part of the thrust sheet under the icecap and the toe. The forces acting upon $\mathrm{P}$ are the horizontal driving force $F_{h}$, originating from the glacier, and the forces resisting movement. Throughout the tectonic movement an equilibrium exists between these forces. This force equilibrium is depicted in vector form in fig. 5 , assuming plane strain (no deformation in the direction of the $y$-axis) and as- 


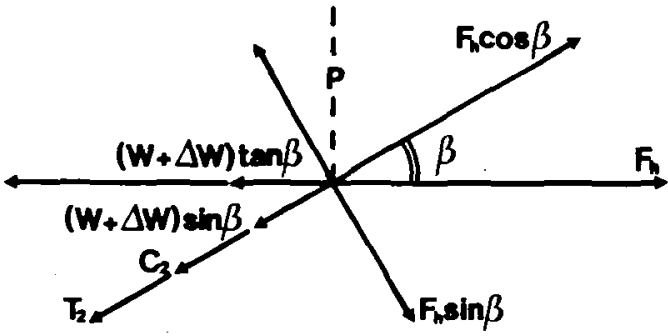

Fig. 5. Balance of forces at the base of plane $P$, equation (4). W $+\Delta \mathrm{W}$ : weight of the toe. $\beta$ : dip of the ramp. $C_{2}$ : cohesive force in the basal layer of the toe. $T_{2}$ : sliding friction along the ramp. $F_{h}$ : the horizontal driving force, the force which is needed to push up the toe.

suming strain is completely taken up in the basal layer of the thrust sheet.

Since the horizontal acceleration may be negliged, the sum of the forces in the $x$-direction applied to the thrust sheet must be zero (Hubbert \& Rubey 1959). During the overthrust movement the following equilibrium of forces in the $x$-direction exists in a thrust sheet of unit width $(y=1$ m):

$F_{h} \cos \beta=(W+\Delta W) \sin \beta+C_{2}+T_{2}$

where $\beta$ is the dip of the upthrust plane, $W+$ $\Delta \mathrm{W}$ is the total weight of the toe volume $\mathrm{V}+$ $\Delta V . C_{2}$ is the cohesive force and $T_{2}$ the sliding friction along the upthrust plane.

The driving force:

$F_{h}=(W+\Delta W) \tan \beta+\frac{C_{2}}{\cos \beta}+\frac{T_{2}}{\cos \beta}$

If $z_{d}$ is the thrust sheet's thickness (z-coordinate of décollement plane) and if the height of the ridge, expressed as a fraction of $z_{d}$ is $\delta z_{d}$, the weight of the toe is:

$W+\Delta W=\varrho_{b} g(V+\Delta V)=\varrho_{b} g \frac{\frac{1}{2} z_{d}^{2}+\delta z_{d}^{2}}{\tan \beta}$

in which $\mathrm{Q}_{\mathrm{b}}$ is the water-saturated bulk density of the thrust sheet and $g$ is the gravitational acceleration.

As a force equals the stress times the area of the surface across which it acts:
$C_{2}=\frac{z_{d}+\delta z_{d}}{\sin \beta} c_{2}$

in which $c_{2}$ is the mean value of the cohesion of the sediments in the toe.

Sliding friction: $T_{2}=T_{w}+T_{1}$, in which $T_{w}$ and $T_{f}$ are the components of friction proportional to the toe's weight $(\mathrm{W}+\Delta \mathrm{W})$ and to the driving force $F_{h}$ respectively.

$$
\begin{aligned}
T_{w} & =\left(1-\lambda_{2}\right) \mu_{2} \varrho_{b} g(V+\Delta V)= \\
& =\left(1-\lambda_{2}\right) \mu_{2} \varrho_{b} g \frac{\left(\frac{1}{2}+\delta\right) z_{d}^{2}}{\tan \beta}
\end{aligned}
$$

$\lambda_{2}$ is the pore water pressure - overburden ratio and $\mu_{2}$ the mean value of the coefficients of friction of the materials. Subscript 2 relates to the toe.

$T_{f}=\left(1-\lambda_{2}\right) \mu_{2} F_{h} \sin \beta$

The driving force can now be solved, because:

$$
\begin{aligned}
F_{h} \cos \beta & =\varrho_{b} g \frac{\left(\frac{1}{2}+\delta\right) z_{d}^{2}}{\sin \beta}+\frac{(1+\delta) z_{d}}{\sin \beta} c_{2}+ \\
& +\left(1-\lambda_{2}\right) \mu_{2} \varrho_{b} g\left\{\frac{\left(\frac{1}{2}+\delta\right) z_{d}^{2}}{\tan \beta}\right\}+F_{h} \sin \beta,
\end{aligned}
$$

sothat

$$
\begin{aligned}
F_{h} & =\frac{c_{2}(1+\delta) z_{d}}{\sin \beta \cos \beta-\left(1-\lambda_{2}\right) \mu_{2} \sin ^{2} \beta}+ \\
& +\frac{\left(1-\lambda_{2}\right) \mu_{2}+\sin \beta}{\sin \beta-\left(1-\lambda_{2}\right) \mu_{2} \sin \beta \tan \beta} \times \\
& \times \varrho_{b} g\left(\frac{1}{2}+\delta\right) z_{d}^{2} \\
F_{h} & =\int_{0}^{z_{d}} \sigma_{h} d z,
\end{aligned}
$$

from which the horizontal stress upon plane $\mathrm{P}$ can be solved:

$$
\begin{aligned}
\sigma_{\mathrm{h}} & =\frac{\mathrm{c}_{2}(1+\delta)}{\sin \beta \cos \beta-\left(1-\lambda_{2}\right) \mu_{2} \sin ^{2} \beta}+ \\
& +\frac{\left(1-\lambda_{2}\right) \mu_{2}+\sin \beta}{\sin \beta-\left(1-\lambda_{2}\right) \mu_{2} \sin \beta \tan \beta} \times \\
& \times 2 \mathrm{e}_{\mathrm{b}} \mathrm{g}\left(\frac{1}{2}+\delta\right) \mathrm{z}_{\mathrm{d}}
\end{aligned}
$$




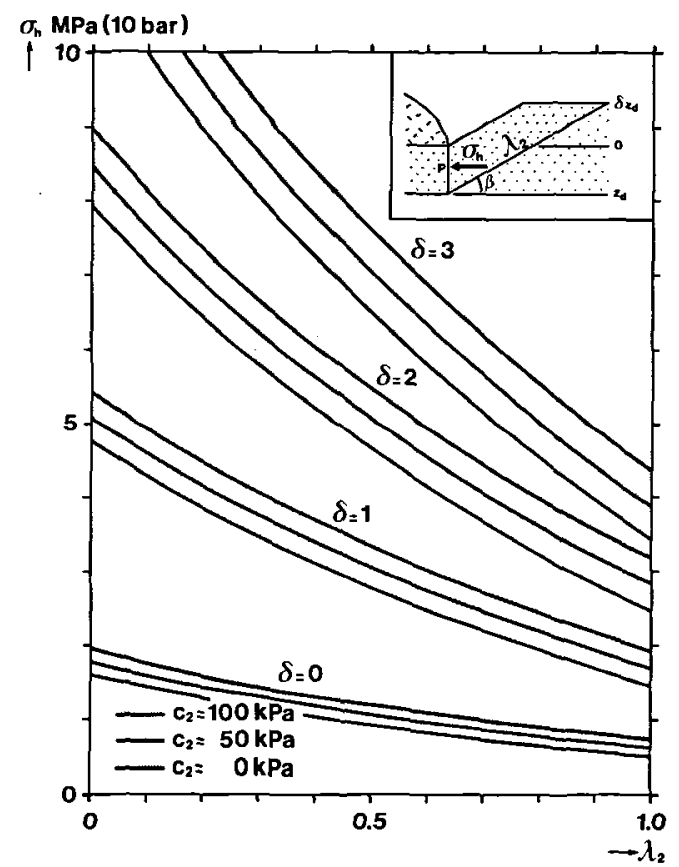

Fig. 6. Horizontal stresses $\left(\sigma_{h}\right)$ across plane $P$ for different values of the cohesion $c_{2}$ in the basal layer of the toe and for different values of $\delta$ (determining the height of the toe above the glacier sole). Thrust sheet thickness $z_{d}=25 \mathrm{~m}$ (Kwintelooijen sandpit, Rhenen).

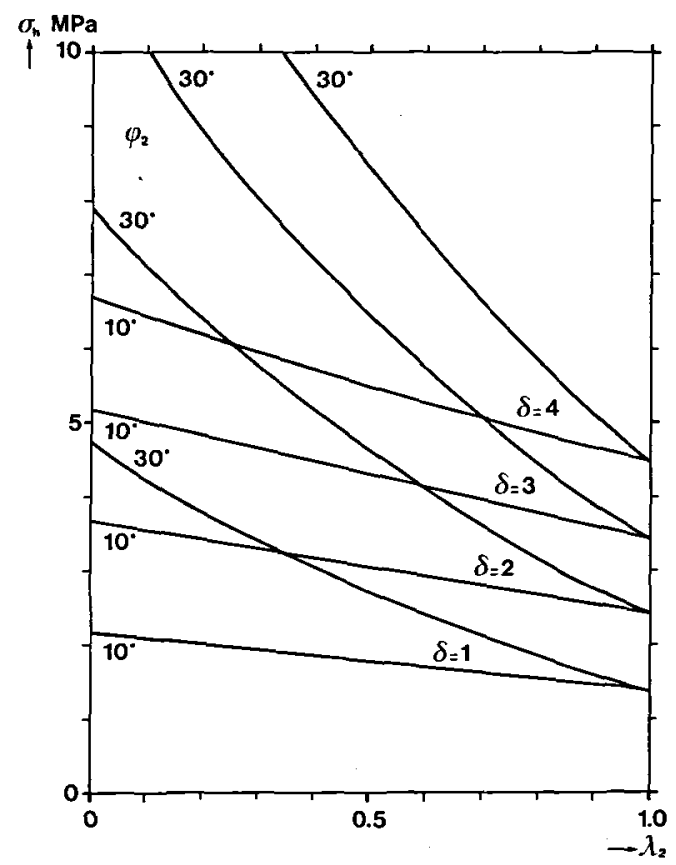

Fig. 7. The effect of a variation of the internal friction angle $\left(\varphi_{2}\right.$ $\left.=\tan ^{-1} \mu_{2}\right)$ in the basal layer of the toe upon the magnitude of the horizontal stress $\sigma_{\mathrm{h}}$.
Figs. 6, 7 and 8 illustrate the relationship between the different parameters and the horizontal driving stress $\sigma_{h}$. In figs. 6 and $7 \mu_{2}=0.58$, corresponding with an angle of internal friction $\varphi_{2}=$ $30^{\circ}$, a low value for dense silty sand (Terzaghi \& Peck 1967). The dip of the upthrust plane $\beta=30^{\circ}$ in figs. 6 and 7.

In fig. 6 is demonstrated that, for increasing elevation of the ridge $\delta z_{d}$, the resistance against movement becomes increasingly dependant of the pore water pressure. As will be expected lowest values of the horizontal stress on plane $P\left(\sigma_{h}\right)$ are reached for $\lambda_{2}=1$ : when the pore water pressure equals the load. The normal stress on the fault plane is zero, so that the only opposing resistance left is caused by the weight of the toe and the cohesion in the upthrust zone. For a completely cohesionless upthrust zone $\left(c_{2}=0\right)$ the minimum stress supporting the toe may be read off fig. 6 . This is the value of $\sigma_{\mathrm{h}}$ found where the lowest of each set of lines intersects the right hand side of the diagram, where $\lambda_{2}=1$. It is provisionally concluded that $\sigma_{h}$ for all but the smallest of ice-pushed ridges far exceeds the maximum basal shear stress in glaciers.

A different choice of the internal friction angle $\varphi_{2}\left(\varphi_{2}=\tan ^{-1} \mu_{2}\right)$ leaves the minimum value of $\sigma_{\mathrm{h}}$ unaffected (see fig. 7). It may be expected that $\sigma_{h}$ will only be less dependant of changes in pore water pressure.

Fig. 8 shows relationships between $\sigma_{h}$ and $\lambda_{2}$ for different dips $\beta$ of the upthrust plane. Lowest values of $\sigma_{h}$ are obtained for dips between $30^{\circ}$ and $40^{\circ}$. This is in agreement with the field observations (see section 2.2), $\sigma_{h}$ increases with decreasing dips, because both the weight $\mathrm{W}+\Delta \mathrm{W}$ and the fault plane area increase.

So far it has been assumed that the upthrust is a Coulomb-type shear zone, where sliding resistance is controlled by intergranular friction. Experiments with large shear displacements (Mandl et al. 1977) show that a shear zone develops once the shear stress reaches a certain value, the peak strength. This peak strength appears to be higher than the Coulomb shear strength. Shear zones are bounded by planes of maximum shear strength (Mandl et al. 1977: 132). After reaching the peak strength the shear stress in the direction of movement rapidly drops ("shear softening") followed by a slow decline to a constant level. The total decrease varies from a few $\%$ to $30 \%$. 


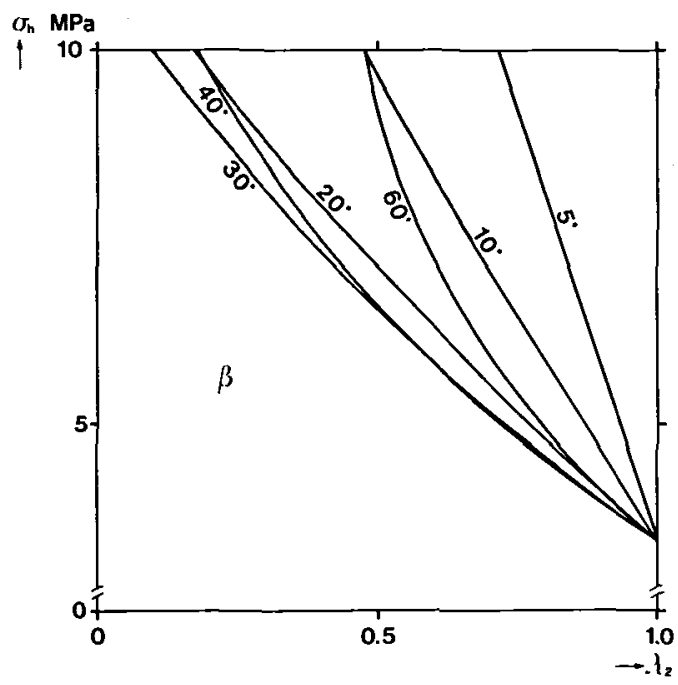

Fig. 8. The effect of a variation of the ramp's $\operatorname{dip} \beta$ upon the magnitude of the horizontal stress $\sigma_{\mathrm{h}}$.

After a certain amount of displacement (typically $1 \mathrm{~m}$ ) shearing concentrates along one or several discrete slip planes on which slickensides are produced. When this state is reached the shear stress remains essentially constant.

An evaluation of the peak strength and the long-term sliding resistance requires the experimental determination of these mechanical parameters. While these are to a large extent unknown and the exact state of stress under the margin area of an icecap (e.g. orientation and magnitude of the principal stresses) remains a guess, it seems wise to stick to the familiar Coulomb model. At least, estimates of $\sigma_{h}$ will be on the low side rather than come out too high. Furthermore, whatever be the kinetics of the upthrust zone: Coulomb slip, simple shear flow under maximum shear stress conditions or viscoplastic flow, all are bounded by the same minimum force, namely the smallest force needed to lift the toe: $(W+\Delta W) \tan \beta$ (fig. 5).

A simple dynamic model of the Gelderse Vallei ice lobe - substrate system

\section{Basic assumptions}

1. In the model chosen here, it is assumed that all sediments respond to stress by a Coulomb-type failure.
2. Décollement occurs in incompetent layers (similar to the shales and evaporites forming the base of "hard rock" thrust sheets and nappes). As a rule this is a clay or loamy layer.

3. Décollement occurs under the marginal zone of the ice lobe and glacial thrust sheets move from underneath the ice edge in a frontal as well as in a lateral direction. Lateral transport directions are almost perpendicular to the long axis of the ice lobe.

4. In the décollement and upthrust zones conditions of high pore water pressure prevail at the time of overthrusting.

5 . The mean basal shear stress $\tilde{\tau}_{b}=0.1 \mathrm{MPa}$; the summed effect of the basal shear stress and the longitudinal stress deviator (Paterson 1981: 100).

6 . The analysis is restricted to two dimensions: deformation is assumed to take place in the $x-z$ plane (plane strain).

\section{Stress field under the glacier margin}

It was demonstrated above that the resistance offered even by an ice-pushed ridge of moderate dimensions far exceeds the basal shear stress $\tilde{\tau}_{b}$. In other words, ice is too weak a substance to sustain stresses in the order of several MPa. If these values were the result of the ice flow, extremely high strain rates and consequently unrealistic flow velocities would have to be supposed. It was mentioned earlier that a dynamic model of an ice lobe - glacial basin system has to deal with the lateral transport of thrust sheets. Even if stresses of the required magnitude do exist within an ice lobe, they will not likely transport considerable masses of sediment in directions deviating almost $90^{\circ}$ from the main direction of ice flow. Also, an ice lobe "bulldozing" its way into the foreland is a very unlikely explanation of the lateral pushing of thrust sheets, as a sediment block lifted several tens of metres will exert a stress on the ice far exceeding the latter's yield strength. (Note: Köster, in his model experiments did not scale down the viscosities of the materials he used. His model ice lobe was made of wood. Köster 1958.)

Thus, in the marginal zone of an ice lobe not only the dynamic equilibrium but also the static equilibrium must be considered; i.e. the ice must balance the weight of the toe.

Rotnicki (1976) was the first to recognize the importance of the static stress field existing along 
a

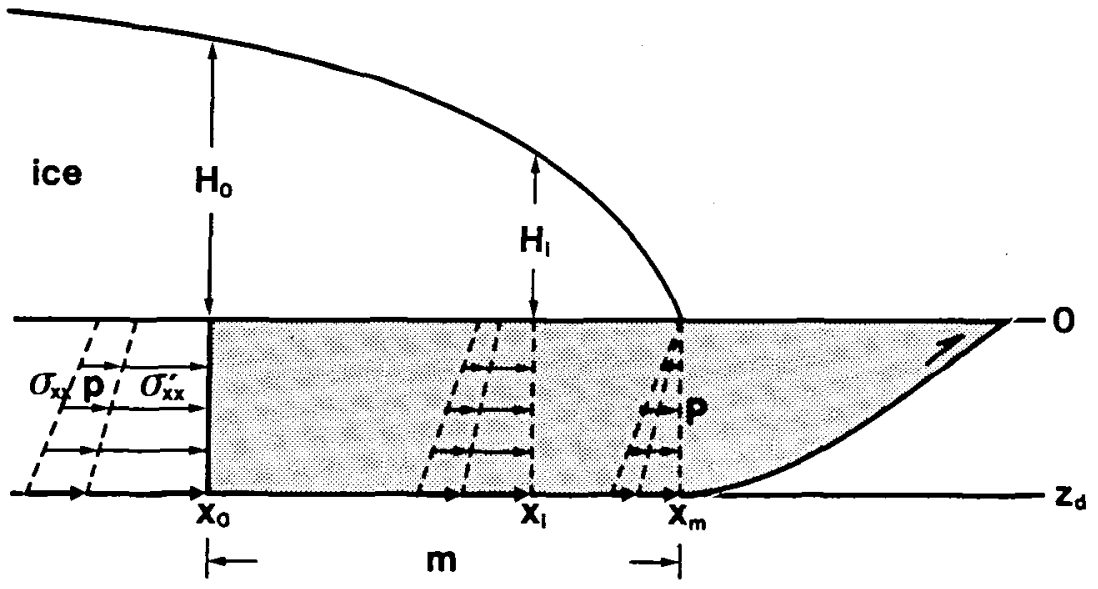

b
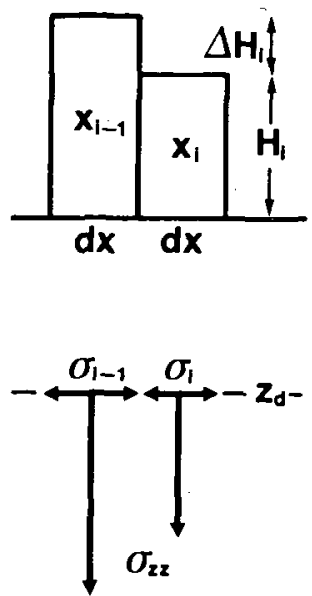

Fig. 9a. The stress system in the marginal zone under an ice lobe. Modified after: Rotnicki (1976) and Hubbert \& Rubey (1959).

Fig. 9b. Vertical and horizontal normal stresses at depth $z_{d}$ underneath two columns of ice.

the margins of an icecap. In his opinion "the phenomena of glacial isostasy and glaciotectonics have one common fundamental cause. It is the same stress system prevailing in the substratum of inland ice." (Rotnicki 1976: 109). In what follows, Rotnicki's theory is slightly modified and supplemented with the Hubbert \& Rubey (1959) theory of overthrust faults.

Icecap profiles show an increasing slope gradient near their edges. To investigate the effect of a steep marginal profile on the stress system in the substratum, let us imagine a plane $D$ at a depth $z_{d}$ under the marginal zone of an ice lobe. Failure is about to take place along this plane (fig. 9a).

Ice thickness in the marginal zone is $\mathrm{H}_{\mathrm{i}}$, varying between $\mathrm{H}_{0}$ (above point $\mathrm{x}_{0}$ ) and 0 at the edge $\left(x_{m}\right)$. Plane $P$ again represents the boundary between intramarginal and extramarginal parts of the thrust sheet. Fig. $9 \mathrm{~b}$ shows a small portion of the ice lobe. Consider a column of ice $x_{i}$, with length $\mathrm{dx}$ and dimensions in $\mathrm{y}$ - and $\mathrm{z}$-directions respectively: $1 \mathrm{~m}$ and $\mathrm{H}_{\mathrm{i}}$. The weight of the ice column plus the weight of the underlying column of sediment cause a vertical stress $\sigma_{z z}$ upon plane D.

If pore water is present in the subglacial sediments the total vertical stress: $\sigma_{z z}=\sigma_{z z}^{\prime}+$ p. $\sigma^{\prime}$ is the effective or intergranular normal stress. The horizontal stress: $\sigma_{x x}=\sigma_{x x}^{\prime}+p \cdot p$ is again the pore water pressure.

From the elastic properties of the material the relationship between the vertical and the horizontal normal stress may be derived:

$\sigma_{x x}^{\prime}=\frac{v}{1-v} \sigma_{x}^{\prime}$

(Means 1976: 253), where $v$ is Poisson's ratio between the principal strains in uniaxial compression. $v=0.5$ for an ideally incompressible material and less than 0.5 for real materials. In the following for Poisson's ratio in granular materials an arbitrary value of 0.20 is chosen.

For convenience $\mathrm{p}$ is again written as a fraction of the total vertical stress: $p_{1}=\lambda_{1} \sigma_{z z}$. As from now on we will only consider the stresses in the $\mathrm{x}$ direction, we leave out the subscript $x \mathbf{x}$; the horizontal normal stress $\sigma_{x x}$ in point $x_{i}$ is: $\sigma_{i}$.

$$
\begin{aligned}
\sigma_{i} & =\frac{v}{1-v}\left(1-\lambda_{1}\right)\left(\varrho_{i} g H_{i}+\varrho_{b} g z_{d}\right)+ \\
& +\lambda_{1}\left(\varrho_{i} g H_{i}+\varrho_{b} g z_{d}\right)
\end{aligned}
$$

where $\varrho_{i}$ and $\varrho_{b}$ are the densities of ice and watersaturated sediment respectively. The horizontal 
stress component under the next column $x_{x-1}$, farther away from the ice-edge is:

$$
\begin{aligned}
\sigma_{i-1}= & \left.\frac{v}{1-v}\left(1-\lambda_{1}\right) \varrho_{\mathrm{g}} g H_{\mathrm{i}-1}+\varrho_{\mathrm{b}} g z_{\mathrm{d}}\right)+ \\
& +\lambda_{1}\left(\mathrm{~g}_{\mathrm{g}} \mathrm{gH} \mathrm{H}_{\mathrm{i}-1}+\varrho_{\mathrm{b}} \mathrm{g} \mathrm{z}_{\mathrm{d}}\right)
\end{aligned}
$$

Because $\sigma_{i-1}$ is larger than $\sigma_{i}$, the stresses do not cancel out, which results in an increment of stress $\Delta \sigma_{i}$ in $x_{i}$, that is directed towards the margin:

$$
\begin{aligned}
\Delta \sigma_{i} & =\sigma_{i-1}-\sigma_{i}=\frac{v}{1-v}\left(1-\lambda_{1}\right) \varrho_{i} g \Delta H_{i}+ \\
& +\lambda_{1} \varrho_{i} g \Delta H_{i}
\end{aligned}
$$

At point $x_{m}$, at the edge of the ice lobe, now acts the summed effect of all $\Delta \sigma_{\mathrm{i}}$ :

$$
\begin{aligned}
\sum_{i=0}^{m} \Delta \sigma_{i} & =\frac{v}{1-v}\left(1-\lambda_{1}\right) \varrho_{i} g \sum_{i=0}^{m} \Delta H_{i}+ \\
& +\lambda_{1} \varrho_{i} g \sum_{i=0}^{m} \Delta H_{i}
\end{aligned}
$$

which we will call the gradient stress. Because

$$
\sum_{\mathrm{i}=\mathbf{0}}^{\mathrm{m}} \Delta \mathrm{H}_{\mathrm{i}}=\mathrm{H}_{0}
$$

(the thickness of the ice column above $\mathrm{x}_{0}$ ), the gradient stress is:

$\sigma_{\text {grad }}=\sum_{i=0}^{m} \Delta \sigma_{i}=\frac{v+\lambda_{1}(1-2 v)}{1-v} \mathrm{~g}_{i} g_{0}$

The resulting gradient force across plane $P$ is:

$F_{\text {grad }}=\int_{0}^{z_{d}} \sigma_{g r a d} d z=\frac{v+\lambda_{1}(1-2 v)}{1-v} \varrho_{i} g H_{0}$

It is this gradient force, added to the force generated by the basal shear stress $\tau_{b}^{-}$, which is thought to be responsible for the movement of glacial thrust sheets.

To assess whether the contribution by the gradient stress field is sufficient, we must consider the total equilibrium of forces acting on either side of the boundary plane $P$ :

$S_{x}^{\prime}+F_{\text {grad }}+\bar{T}_{b}-T_{x}-F_{h}=0$

The first term represents the thrust sheet's own weight which was canceled in (11):

$\sigma_{\mathrm{x}}^{\prime}=\frac{v}{1-v}\left(1-\lambda_{1}\right) \varrho_{\mathrm{b}} \mathrm{g} z_{\mathrm{d}}$, sothat:

$S_{x}^{\prime}=\int_{0}^{z_{d}} \sigma_{x}^{\prime} d z=\frac{v\left(1-\lambda_{1}\right)}{2(1-v)} \varrho_{b} g z_{d}^{2}$

The third term represents the horizontal force generated in the marginal zone by the basal shear stress:

$\overline{\mathrm{T}}_{\mathrm{b}}=\int_{\mathrm{x}_{0}}^{\mathrm{x}_{\mathrm{m}}} \tilde{\tau}_{\mathrm{b}} \mathrm{dx}$

$T_{x}$ is the sliding friction in the décollement zone. If we assume a Coulomb sliding resistance at the base of the thrust sheet:

$$
\begin{aligned}
T_{x} & =\int_{x_{0}}^{x_{m}} \tau_{x} d x=\left(x_{m}-x_{0}\right)\left[c_{d}+\left(1-\lambda_{d}\right) \varrho_{b} g z_{d} \mu_{d}\right]+ \\
& +\left(1-\lambda_{d}\right) Q_{i} g \mu_{d} \int_{x_{0}}^{x_{m}} H_{i} d x
\end{aligned}
$$

where $c_{d}$ is cohesion in the décollement zone, $\lambda_{d}$ is the pore water pressure - overburden ratio in the décollement zone and $\mu_{d}$ is the coefficient of internal friction of the décollement layer material.

$$
\int_{x_{0}}^{x_{m}} H_{i} d x
$$

represents the volume of the marginal ice slab.

$F_{h}$ is the horizontal force caused by friction in the upthrust zone and the weight of the toe (equation 6).

To illustrate how the different elements of the equilibrium relate to each other we will have a look at table 1. For different values of the parameters $\lambda, \mu$ and $c$ values are given of $S_{x}^{\prime}, F_{g r a d}, \dot{T}_{b}$, $T_{x}$ and $F_{h}$. Thrust sheet and toe dimensions apply 
to the Rhenen situation. The thrust sheet is $\mathbf{5 0 0}$ $\mathrm{m}$ long, which is the maximum length in Kwintelooijen. The volume of the marginal ice slab:

$\int_{x_{0}}^{x_{m}} H_{i} d x=8.75 \times 10^{4} \mathrm{~m}^{3}$, an arbitrary value.

It will be apparent from table 1 that the most favourable circumstances for glacial thrusting occur when the temperatures under the ice margin are above freezing point (columns 1 and 2), the décollement layer consists of water saturated clay (columns 4 and 5) and the pore water pressure in the upthrust zone is at maximum (columns 8 and 9).

Values in column 1 are not very realistic, as the pore water pressure in the substratum is not likely to reach the overburden pressure. This situation supposes a pressure head higher than the ice surface, which would cause the ice lobe to float.

$\lambda_{1}=0.85$ (column 2) corresponds with a water level about $80 \%$ of the ice thickness $\mathrm{H}_{\mathrm{i}}$. The total driving force resulting from the gradient and the dynamic stress field amounts to about $100 \mathrm{MN}$ (10 Newton).

If the base of the thrust sheet consists of a clay layer and if the overburden is totally supported by the pore water pressure in the clay layer $\left(\lambda_{d}=\right.$ 1), sliding friction $T_{x}$ will be minimal. The thrust sheet and the overlying ice are in an incipient floating state and only the cohesion of the décollement clay plus the resistance by the toe oppose the driving force.

How can a sufficiently high pore water pressure be maintained long enough to promote thrust sheet movement? The answer must be sought in the extreme low permeability of clays: in the order of $10^{-4}$ to $10^{-7} \mathrm{~m} . \mathrm{s}^{-1}$ (Terzaghi \& Peck 1967: 55). If a sediment of low permeability is rapidly subjected to a load, the sediment tends to build up a pore water pressure, which will not readily disappear because the water can not escape quickly. The pore water pressure may approach the oberburden pressure, sothat the movement of overthrust sheets is essentially frictionless (Roberts 1972). The only friction left that must be overcome is the cohesion. After a certain amount of displacement cohesion (or, rather adhesion) of the décollement plane drops

Table 1. Values (in $\mathrm{MN}=10^{6}$ Newton) of the elements of equation (15), for an ice-thickness $\left(\mathrm{H}_{0}\right)$ of $250 \mathrm{~m}$ and a marginal zone $\mathrm{m}=$ $500 \mathrm{~m}$.

Ramp slope $(\beta)=30^{\circ}$ on columns 8 to 11 and $10^{\circ}$ in columns 12 and 13 .

Note: bold figures are discussed in the text.

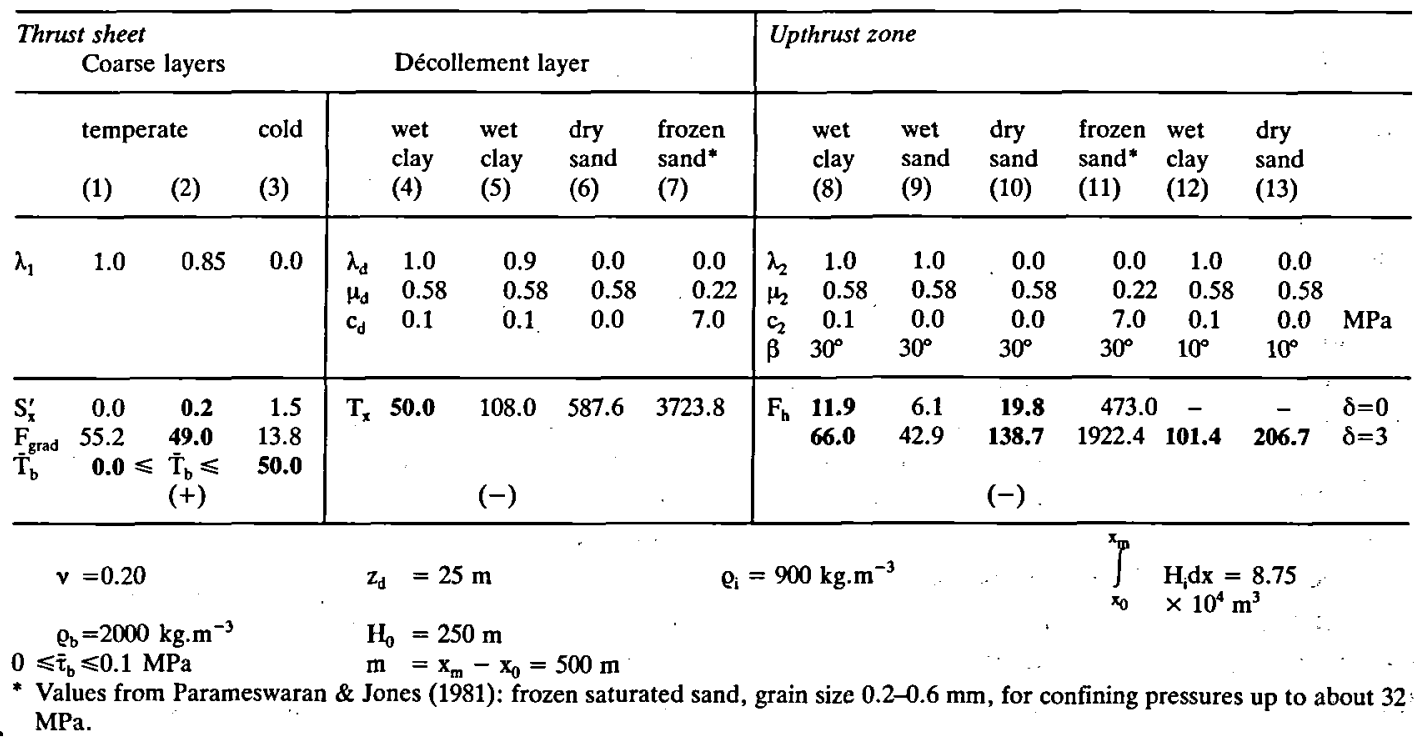


below the initial value. While the mechanical parameters of the décollement clay at Kwintelooijen are unknown, an arbitrary value for $c_{d}$ had to be chosen. Cohesion is $0.1 \mathrm{MPa}$, therefore the strengths of the clay and the glacier ice are of the same order of magnitude.

We will now look at the frontal part of the thrust sheet. Minimal resistance in the toe occurs if the upthrust plane cuts saturated unfrozen sand (column 9). It may be seriously doubted however, that a sandy soil close to a large icecap contains significant amounts of unfrozen water. On the other hand, in clay and silt a large proportion of the water remains unfrozen even at temperatures below $-15^{\circ} \mathrm{C}$ (Yong \& Warkentin 1975: 412).

We now arrive at the following results. At the initiation of glacial thrusting no part of the toe is above the surface, so $\delta=0$. If loading by an advancing ice lobe is sufficiently rapid, the shear strength of the décollement clay is reduced to 50 MN over the distance of the marginal zone, 500 $\mathrm{m}$. An upthrust plane is formed which follows stepwise clay layers and sand layers containing only small amounts of ice ("dry permafrost"). The initial toe resistance varies between 12 and $20 \mathrm{MN}$ (columns 8 and 10 , for $\sigma=0$ ), depending on the abundance of clay layers in the toe. Thus, the glacial stress field initially has to overcome at least a resistance of $62 \mathrm{MN}$, more likely a value near $70 \mathrm{MN}$ (total of columns 4 and 10 ).

An ice lobe $250 \mathrm{~m}$ thick at $500 \mathrm{~m}$ from the margin, produces $50 \mathrm{MN}$, for $\tilde{\tau}_{b}$ approaching 0 , as can be expected near the lateral margins, or $100 \mathrm{MN}$, at the frontal margin, where $\tilde{\tau}_{b}$ may be as high as $0.1 \mathrm{MPa}$. The ice lobe seems to be just about capable of starting the movement of our thrust sheet.

As soon as the toe starts to rise $F_{h}$ will increase. If the toe is pushed up a $30^{\circ}$ ramp to a level $100 \mathrm{~m}$ above the décollement $(\delta=3)$ the maximum value of $F_{h}$ is somewhere between 70 and $140 \mathrm{MN}$ (columns 8 and 10). But, looking at the profile, fig. 2, we will see that the average dip is about $10^{\circ}$. This implies that the final resistance offered by the toe may vary from 100 to $200 \mathrm{MN}$ (columns 12 and 13).

At the same time $T_{x}$ decreases, as sliding soon takes place along a number of discrete slip planes and the area of the décollement plane gradually decreases.
From the basal shear stress $50 \mathrm{MN}$ can be expected at most and as the thrust sheet is transported away this contribution even drops below this value. In order to maintain the transport of thrust sheets up to their final position, the ice lobe apparently needs to increase its thickness.

To give an idea of the order of magnitude of the forces in case both the substratum and the foreland are frozen, values of $T_{x}$ and $F_{h}$ are calculated (columns 7 and 11). The mechanical parameters $\mu$ and $c$ are determined by triaxial testing of frozen saturated sand (Parameswaran \& Jones 1981). Although the long-term shear strength of frozen sand will be considerably less, glacial thrusting is obviously promoted by a high pore water pressure in the décollement and the upthrust zone.

It is now time to critically review the assumptions which are made in the previous discussion. It has been assumed that:

1. water is an incompressible medium. For the stresses under consideration this is a reasonable assumption.

2. the stress gradient $\Delta \sigma_{i}$ is the same at all levels in the thrust sheet, which evidently is not true. The stress gradient dissipates at lower levels in the substratum, due to energy loss by e.g. elastic strain, compaction and the production of heat by intergrainal friction. This implies that the simple linear relationship between the ice thickness $\mathrm{H}_{0}$ and $F_{\text {grad }}$ will need correction.

3. the average basal shear stress $\tilde{\tau}_{b}$, applied to the top of the thrust sheet remains constant throughout the whole thickness. The same restriction applies here as to the previous assumption.

4. the greatest principal stress $\sigma_{1}$ is vertical throughout the whole marginal zone and horizontal near the edge (near plane P). In fact, as the contribution by $\Sigma \Delta \sigma_{i}$ increases, $\sigma_{1}$ rotates from a vertical orientation well away from the margin to a more horizontal orientation towards the edge where upthrusting takes place. This effect tends to reduce $F_{\text {grad. }}$.

5. no energy loss occurs during the movement of a thrust sheet. This is also a simplification. Energy is consumed by elastic strain in all parts of the thrust sheet, by plastic strain and the production of heat in the deforming décollement clay and by internal friction and bending as the thrust sheet climbs a ramp (e.g. near plane $\mathbf{P}$ ).

6. ice thickness is $250 \mathrm{~m}$ at a distance of $500 \mathrm{~m}$ 
from the edge. These are arbitrary values, chosen to illustrate the argument. As the glacial basin is 10 to $12 \mathrm{~km}$ wide near Kwintelooijen (fig. 1), a zone several $\mathrm{km}$ wide should be considered. Owing to the uncertain nature of many mechanical parameters the thickness of the icelobe in the Gelderse Vallei cannot be determined more exactly at present. The least that can be said is that $250 \mathrm{~m}$ appears to be a minimum value and that, to maintain a stress field of the required magnitude in the marginal zone, the ice lobe probably had to be even thicker. This holds even more where tectonic transport directions are almost at right angles with the main direction of ice flow. Here, the basal shear stress will be less than $0.1 \mathrm{MPa}$.

\section{Conclusions}

Most models of glacial thrusthing deal with the question of friction in the décollement zone. Yet the pore water mechanism alone is not enough to explain the lifting of considerable sediment masses. The maximum basal shear stress in a glacier is just enough to overcome the sliding resistance of the substratum, but is unable to build up all but the smallest of ice-pushed ridges. If the gradient stress field is taken into account, as suggested by Rotnicki (1976), we are able to explain the initiation and transport of lifesize thrust sheets.

A frozen bed, consisting of frozen saturated sediments, is not a prerequisite for the formation of glacial thrust sheets, but rather appears to hinder the process.

After the first thrust sheet has appeared from underneath the ice edge, the next one is formed further away. The gradient stress field causing the formation of the second and younger thrust sheets is the result of the total weight of the ice lobe and older thrust sheets. Tectonic movement stops when the total energy consumed by the system approaches the maximum amount that can be produced by a given glacial stress field. Movement will only resume if the ice lobe grows thicker, thus increasing the static component. Consequently, higher and wider ice-pushed ridges are formed around thicker ice lobes and smaller ridges are formed around thinner ice lobes.
In broad outline the formation of ice-pushed ridges around the Gelderse Vallei may be pictured as in fig. 10. The ice lobe, occupying the Gelderse Vallei, together with the substratum and the surrounding ice-pushed ridges are regarded as a steady state system.

The front of the Saalian ice sheet reached the area of the present day Gelderse Vallei from the north. The flowing out of a small ice lobe from the glacier front was either determined by the relief in the former Rhine-Meuse drainage system, or by the local absence of permafrost near water courses and under ice-dammed lakes.

Three factors control the formation of glacial thrust sheets:

- (1) the speed of the ice advance, determining the magnitude of the pore water pressure in impermeable sediments and

- a critical combination of (2) ice thickness and

(3) depth of a suitable décollement layer.

As the ice lobe grows this critical thickness is reached and the first thrust sheets start to escape along the margins. Advancing further, the ice lobe becomes wider and thicker, simultaneously enlarging the gradient stress field. Each time a thrust sheet climbs the next ramp (fig. 10b and 10d) the ice lobe subsides, whereby energy for the tectonic transport is released. To maintain the process, potential energy has to be supplied by the continuous flow of ice into the system.

Ice lobe thickness at any one time appears to be determined by the profile of the ice sheet (mainly depending on mass balance and bedrock conditions) and the resistance offered by the icepushed ridge. The growing ridge increasingly resists the gradient stress field, forcing the ice lobe to increase its surface gradient until the maximum thickness under the circumstances is reached. Subsequent movement consumes the potential energy thus stored in the system. The ice lobe subsides and eventually the process dies out.

It is worthwile to note that the thrust sheets of the Utrecht Ridge are of only moderate dimensions. Thrust sheets in other areas are reported to have a thickness of $88 \mathrm{~m}$ (Northern Veluwe, Zandstra 1971), $100 \mathrm{~m}$ (Archemerberg, de Jong 1962), 80 to $100 \mathrm{~m}$ (Itterbeck - Uelsen, Richter et al. 1950) and $100 \mathrm{~m}$ (Muskau fold belt, Viete 1960).

The dimensions of the Rhenen thrust sheets 

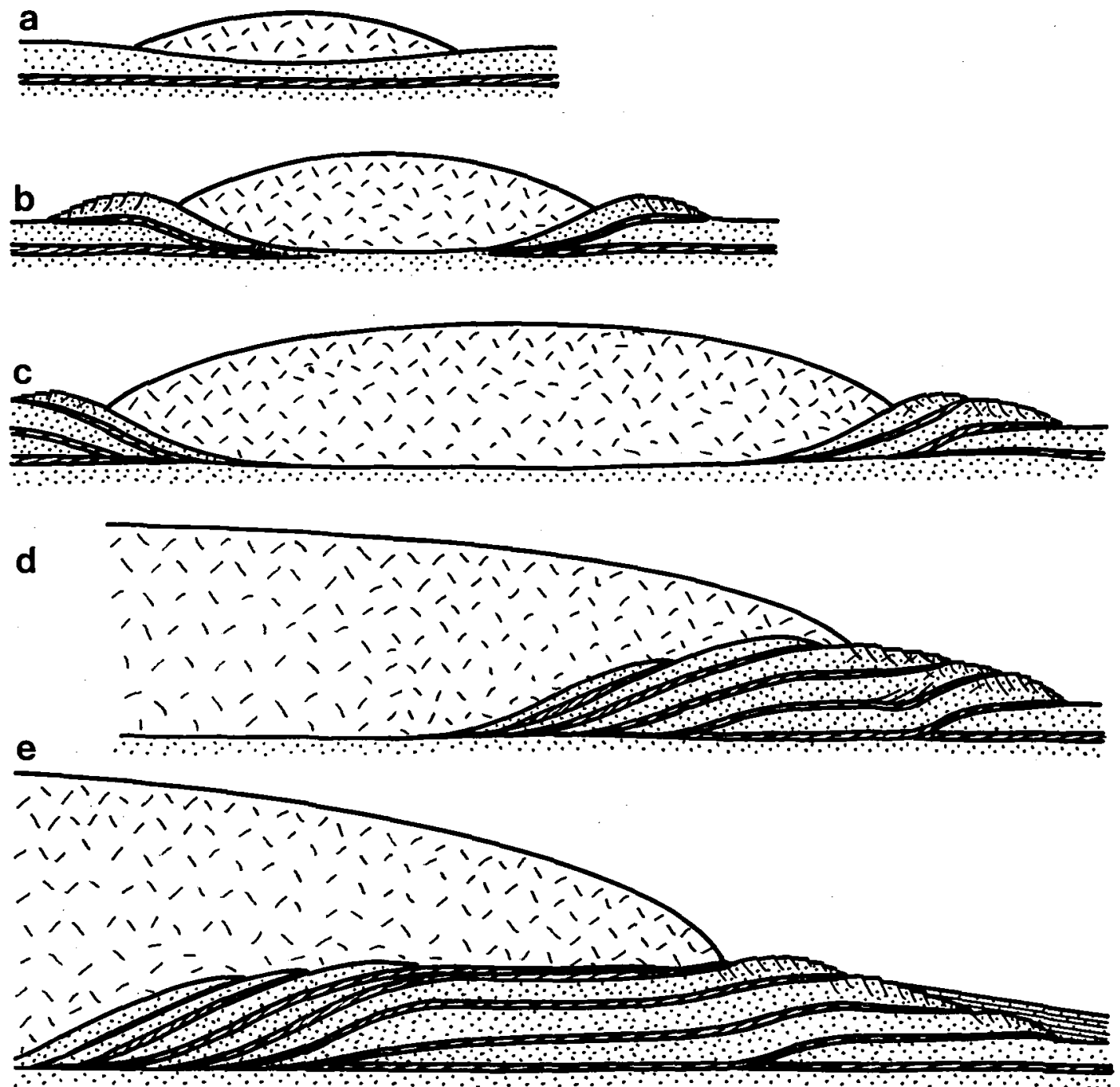

$\mathbf{E}-$

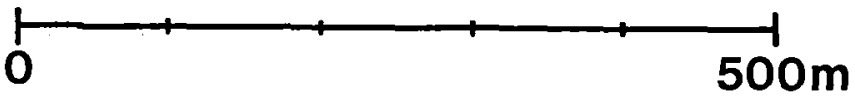

Fig. 10. An outline of the development of the Utrecht Ridge at the western margin of the Gelderse Vallei ice lobe; east-west profiles taken along the Kwintelooijen sandpit.

In fig. 10a an ice lobe invades the area, probably following the course of a river system. While the ice lobe continues to grow southward thrust sheets start to form as soon as the ice lobe thickness reaches a critical value (fig. 10b). Décollement is favoured by a clay layer at a depth of $25 \mathrm{~m}$ below the surface (hatched layer).

The growing ice mass added to the mass of older thrust sheets supply the potential energy to move younger thrust sheets away from the centre of the Gelderse Vallei (fig. 10c to e). Younger thrust sheets are formed in front of older ones. The exposed parts of the thrust sheets (the toes) are subjected to normal faulting and erosion by meltwater. On the western flank of the Utrecht Ridge glaciofluvial deposits are laid down (fig. 10e).

and the glacial basin from which they were removed are in agreement with the picture outlined above. The ridge is built up of 20 thrust sheets at most with an average length of about $250 \mathrm{~m}$. Un- folding the structures brings us to the center of the Gelderse Vallei.

Circumstances promoting the mechanism of glacial thusting proposed here, are most likely to 
be found with a glacier advance, or at least, the growth of an ice lobe. Then, one of the major conditions can be met: reduced sliding friction brought about by a high pore water pressure in a potential décollement layer. Also the lithostratigraphical evidence in the Gelderse Vallei seems easier to fit into a model of ice advance than into a model of general ice retreat. Whether this argument also holds in the case of the lines of icepushed ridges farther to the north in the Netherlands, must be concluded from a critical reexamination of structural and lithostratigraphical data from these areas.

Acknowledgements. I wish to thank the following persons, who contributed in any way to the present article.

Frof. Dr. G. C. Maarleveld advised on the periglacial aspects. Dr. I. v. d. Molen discussed the tectonic aspects and suggested several modifications which improved the article. Mr. N. Bosman corrected the English version of the text. Mrs. J. Graatsma-Griemelijkhuizen typed the draft. Mrs. L. B. M. Overdiep photographed the figures and in many other ways helped me to finish the article.

\section{Dansk sammendrag}

På grundlag af detaillerede strukturgeologiske og geomorfologiske studier af isoppressede rygge og flager ved Gelderse $\mathbf{i}$ det centrale Holland opstiller forfatteren en generel model for flagedannelse. Ved Gelderse er de enkelte flager op til 25 meter tykke og op til 250 meter lange og består fortrinsvis af groft smeltevandssand, der er bevæget sammenhængende som stive legemer.

Flagedannelse kan ikke alene forklares ved horisontalt tryk. Det maksimale basale shear stress ved isbasis er af en størrelsesorden, der netop er stor nok til at overvinde friktionen ved isbevægelsen, men ikke stort nok til at frembringe opskydninger, som de kan ses i felten, men medregner man ogsả normalstresset, frembragt af isens vagt, er det muligt, at få dannet flageopskydninger. Opskydninger dannes fortrinsvis ved randen af avancerede ismasser, hvor også et porevandsovertryk i decollement zonen kan reducere den basale friktion og hvor der samtidig er et passende forhold mellem istykkelse og dybde til en potentiel decollement zone.

Den første flage dannes som følge af isbelastning og isbevægelse. Den næste flage dannes som resultat af isbelastning samt belastningen af den først dannede flage, men ved hver opskydning (flagedannelse) bruges opsummeret energi, og for at processen skal fortsatte, behøves der derfor en kontinuert tilførsel af is. Tilsvarende vil der være en sammenhæng mellem den højde, en flage kan skubbes op til og istykkelsen. Store opskydninger kræver en større istykkelse. På dette grundlag skønnes det, at isloben i Gelderse depressionen har haft en tykkelse på mindst 250 meter.

\section{References}

Banham, P. H., 1975: Glacitectonic structures: a general discussion with particular reference to the contorted drift of Norfolk. In: A. E. Wright \& F. Moseley (eds.): Ice Ages: ancient and modern. Geol. Journal, Spec. Issue 6, 69-94, Liverpool.

Berthelsen, A., 1979: Recumbent folds and boudinage structures formed by subglacial shear: an example of gravity tectonics. Geol. en Mijnbouw, 58 (2), 253-60.

Boulton, G. S., 1979: Processes of glacier erosion on different substrata. Journ. of Glaciology, Vol. 23, No. 89, 15-38.

Boulton, G. S. \& A. S. Jones, 1979: Stability of temperate ice caps and ice sheets resting on beds of deformable sediment. Journ. of Glaciology, Vol. 24, No. 90, 29-43.

Cate, J. A. M. ten \& G. C. Maarleveld, 1977: Toelichting op de legenda. Geomorfologische kaart van Nederland 1:50.000. - Stichting v. Bodemkart., Wageningen, Rijks Geol. Dienst, Haarlem.

Christiansen, E. A. \& S. H. Whitaker, 1976: Glacial thrusting of drift and bedrock. In: Glacial till. An interdisciplinary study. R. F. Legget (ed.). Royal Society of Canada, Spec. Publ. 12, Nat. Res. Counc. of Canada, Ottawa.

Doppert, J. W. Chr., G. H. J. Ruegg, C. J. van Staalduinen, W. H. Zagwijn \& J. G. Zandstra, 1975: Lithostratigrafie. Formaties van het Kwartair en Boven-Tertiair in Nederland. In: Zagwijn, W. H. \& C. J. van Staalduinen: Toelichting bij geologische overzichtskaarten van Nederland, 11-56. Rijks Geol. Dienst, Haarlem.

Gripp, K., 1929: Glaciologische und geologische Ergebnisse der Hamburgischen Spitzbergen-Expedition 1927. Abh. Naturwiss. Ver. Hamburg, Bd. XXII, 145-248.

Hobbs, B. E., W. D. Means \& P. F. Williams, 1976: An outline of structural geology. 571 pp. John Wiley \& Sons, New York.

Hobbs, P. V., 1974: Ice physics. 820 pp. Clarendon Press, Oxford.

Horsfield, W. T., 1977: An experimental approach to basement-controlled faulting. Geol. en Mijnb., 56 (4), 363-70.

Hsü, K. J., 1969: Role of cohesive strength in the mechanics of overthrust faulting and of landsliding. Geol. Soc. America Bull., 80 (6), 927-52.

Hubbert, M. K. \& W. W. Rubey, 1959: Role of fluid pressure in mechanics of overthrust faulting. Geol. Soc. America Bull., 70 (2), 115-66.

Jaeger, J. C. \& N. G. W. Cook, 1979: Fundamentals of rock mechanics. $620 \mathrm{pp}$. Chapman and Hall, London.

Jelgersma, S. \& J. B. Breeuwer, 1975a: Toelichting bij de kaart glaciale verschijnselen gedurende het Saalien, 1:600.000. In: W. H. Zagwijn \& C. J. van Staalduinen (eds.): Toelichting bij geologische overzichtskaarten van Nederland, 93-103. Rijks Geol. Dienst, Haarlem.

Jelgersma, S. \& J. B. Breeuwer, 1975b: Toelichting bij de geologische overzichtsprofielen door Nederland. In: W. H. Zagwijn \& C. J. van Staalduinen (eds.): Toelichting bij geologische overzichtskaarten van Nederland, 91-93. Rijks Geol. Dienst, Haarlem.

Jong, J. D. de, 1952: On the structure of the preglacial Pleistocene of the Archemerberg (prov. of Overijssel, Netherlands). Geol. en Mijnbouw, N.S. 14, 86-90.

Jong, J. D. de, 1962: Nijverdal and Archemerberg. Meded. Geol. Stichting, N.S., No. 15, 55-56.

Kălin, M., 1971: The active push moraine of the Thompson glacier, Axel Heiberg Island, Canadian Arctic Archipelago, Canada. Diss., 68 pp. Montral.

Köster, R., 1958: Experimenteller Beitrag zur Mechanik von Stauchungszonen. Meyniania, Bd. 6, 60-84. Kiel.

Kupsch, W. O., 1962: Ice-thrust ridges in western Canada. Journ. of Geol., 70 (5), 582-94. 
Laubscher, H., 1973: Jura Mountains. In: K. A. de Jong \& R. Scholten (eds.): Gravity and tectonics, 217-27. John Wiley $\&$ Sons, New York etc.

Maarleveld, G. C., 1953: Standen van het landijs in Nederland. Boor en Spade, 6, 95-112.

Maarleveld, G. C., 1981: The sequence of ice-pushing in the Central Netherlands. Meded. Rijks Geol. Dienst, 34 (1), 2-6.

Maarleveld, G. C. \& G. W. de Lange, 1977: Geomorfologie. In: S. M. ten Houte de Lange (ed.): Rapport van het Veluwe-onderzoek, 15-24. Pudoc, Wageningen.

Mackay, J. R. \& W. H. Mathews, 1964: The role of permafrost in ice-thrusting. Journ. of Geol. 72, 378-80.

Mandl, G., L. N. J. de Jong \& A. Maltha, 1977: Shear zones in granular material. Rock Mechanics, 9, 95-144.

Means, W. D., 1976: Stress and strain. 352 pp. Springer-Verlag, New York etc.

Moran, S. R., 1971: Glaciotectonic structures in drift. In: R. P. Goldthwait (ed.): Till: a symposium, 127-148. Ohio State Univ. Press.

Moran, S. R., L. Clayton, R. LeB. Hooke, M. M. Fenton \& L. D. Andriashek, 1980: Glacier-bed landforms of the prairie region of North-America. Journ. of Glaciology, 25 (93), 457-76.

Parameswaran, V. R. \& S. J. Jones, 1981: Triaxial testing of frozen sand. Journ. of Glaciology, 27 (95), 147-55.

Paterson, W. S. B., 1981: The physics of glaciers. 588 pp. Pergamon Press, Oxford etc.

Raleigh, C. B. \& D. T. Griggs, 1963: Effect of the toe in the mechanics of overthrust faulting. Geol. Soc. America Bull., 74 (7), 819-30.

Richter, W., H. Schneider \& R. Wager, 1950: Die Saaleeiszeitliche Stauchzone von Itterbeck-Uelsen (Grafschaft Bentheim). Z. d. Dtsch. Geol. Ges., B.102/I, 60-75.

Roberts, J. L., 1972: The mechanics of overthrust faulting: a critical review. Rept. Sec. 3, 24th Internat. Geol. Congr., 593-98. Ottawa.

Rotnicki, K., 1976: The theoretical basis for and a model of the origin of glaciotectonic deformations. Quaestiones Geographicae, 3, 103-39.
Ruegg, G. H. J., 1981: Ice-pushed Lower and Middle Pleistocene deposits near Rhenen (Kwintelooijen): sedimentarystructural and lithologic/granulometrical investigations. Meded. Rijks Geol. Dienst. 35-2, 165-78.

Schindler, C., H. Röthlisberger \& M. Gyger: Glaziale Stauchungen in den Niederterrassen-Schottern des Aadorfer Feldes und ihre Deutung. Eclogae geol. Helv., 71/1, 15974.

Terzaghi, K., 1936: Simple tests determine hydrostatic uplift. Engineering News-Record, 116, June 18, 872-75.

Terzaghi, K. \& R. B. Peck, 1967: Soil mechanics in engineering practice. 706 pp. John Wiley \& Sons, New York.

Viete, G., 1960: Zur Entstehung der glazigenen Lagerungsstörungen unter besonderer Berücksichtigung der Flözdeformationen im mitteldeutschen Raum. Freiberger Forschungshefte, C-78, 1-257.

Visscher, H. A., 1972: Lexicon voor fysiche geografie. 240 pp. Het Spectrum, Utrecht.

Wateren, F. M. van der, 1981a: Geomorfologie en glaciale tektoniek van enkele middennederlandse stuwwallen. Unpublished M.D. thesis, 151 pp. Amsterdam, Utrecht.

Wateren, F. M. van der, 1981b: Glacial tectonics at the Kwintelooijen sandpit, Rhenen, the Netherlands. Meded. Rijks Geol. Dienst, 35-7, 252-68.

Wee, M. W. ter, 1962: The Saalian glaciation in the Netherlands. Meded. Geol. St., N.S. 15, 57-76.

Yong, R. N. \& B. P. Warkentin, 1975: Soil properties and behaviour. 454 pp. Elsevier Scient. Publ. Comp., Amsterdam etc.

Zagwijn, W. H., 1973: Pollenanalytic studies of the Holsteinian and Saalian beds in the northern Netherlands. Meded. Rijks Geol. Dienst, N.S. 24, 139-56.

Zandstra, J. G., 1971: Geologisch onderzoek in de stuwwal van de oostelijke Veluwe bij Hattem en Wapenveld. Meded. Rijks Geol. Dienst, N.S. 22, 215-59.

Zandstra, J. G., 1981: Petrology and lithostratigraphy of icepushed Lower and Middle Pleistocene deposits at Rhenen (Kwintelooijen). Meded. Rijks Geol. Dienst, 35-3, 178-91. 